\title{
Erratum
}

\section{Should we T-cell deplete sibling grafts for acute myeloid leukaemia in first remission?}

S Chakrabarti and DI Marks

\author{
Bone Marrow Transplantation (2004) 33, 465. \\ doi:10.1038/sj.bmt.1704449
}

Correction to: Bone Marrow Transplantation (2003) 32, 1039-1050. doi:10.1038/sj.bmt.1704281

This was published inadvertently as a Meeting Report and should have been published as a Mini review. 